\title{
Traditional Ecological Knowledge, Sacred Groves and Conservation of Biodiversity in the Pachmarhi Biosphere Reserve of India
}

\author{
Chandra Prakash Kala \\ Ecosystem \& Environment Management, Indian Institute of Forest Management, Bhopal, India. \\ Email: cpkala@yahoo.co.uk
}

Received March 21 ${ }^{\text {th }}, 2011$; revised July 19 ${ }^{\text {th }}, 2011$; accepted August $23^{\text {th }}, 2011$.

\begin{abstract}
The sacred groves in the Pachmarhi Biosphere Reserve (PBR) of India were studied to understand the concept of traditional ecological and biodiversity conservation systems. A questionnaire survey was conducted in the selected villages of the PBR along with the survey of sacred groves. In 10 selected villages of the PBR 7 sacred groves were managed by Mawasi and 16 sacred groves by Gond tribal communities. Different deities were worshipped in the sacred groves and each grove was named after the deity dwelling in the respective sacred grove. A total of 19 such deities were recorded during the survey worshipped by the local people. In study area, various traditional customs associated with sacred groves were in practice. The sacred groves were rich in plant genetic diversity and were composed of many ethnobotanically useful species, including wild edible fruits, medicinal plants, fodder, fuelwood and timber yielding species. Given the importance of conservation of biodiversity and ecosystem attempts should be made to maintain the sanctity of sacred groves.
\end{abstract}

Keywords: Sacred Grove, Biosphere Reserve, Biodiversity Conservation, Traditional Ecological Knowledge, Gond \& Mawasi Tribe

\section{Introduction}

The indigenous communities still practice some cultural linkages between social and biophysical ecosystems. They have not only co-evolved with the surrounding environmental conditions but also they have maintained it in a diverse and productive state on the basis of traditional practices and beliefs $[1,2]$. The necessity of natural resources for human survival had made them to evolve a system having some customary laws and practices, which in long run might help to conserve the surrounding natural resources. Religion, being a powerful instrument for convincing people, has always been used for meeting the desired objectives of the society. The various religious philosophies have contributed significantly in the conservation of forests, biodiversity and landscapes by promulgating customary norms, practices and beliefs. However, with the advent of commercial interests in the forests and biodiversity, in most parts of the world, the indigenous philosophy and practices including religious approach adopted by the local communities for conservation of biodiversity have generally overlooked [3]. Weakening of traditionally inherited conservation practices and dominance of commercial interests over the period of time have invited several irregularities and concerns in the conservation and management of natural resources.

Fortunately, some prominent live examples of traditional forms of biodiversity conservation still exit and in practice, which include the philosophy of sacred groves, sacred species and sacred landscape. The evidences suggest that sacred grove concept of biodiversity conservation had adopted by various indigenous communities worldwide, such as, aboriginals of Australia, Caucasus Mountains community, ancient Slavic people, German tribes [4], Greek and Romans, Kikuyu of Africa [5], and Mbeere tribe of East Africa [6]. Before the spread of Christianity and Islam the sacred groves covered much of the Middle East and Europe. The sacred grove concept is still relevant and exists today, especially in many parts of Asia, Africa and Mexico [7]. In India, over 13,720 sacred groves have been enlisted [8] that exist across diverse topography and climatic conditions from down south to north however, the actual number is thought to be much larger than that [2].

The sacred groves, in India, are known by different 
names at different places, such as 'Devray' in Maharastra, 'Devarkand' and 'Siddarvanam' in Karnataka, 'Oraans', 'Kenkari', 'Malvan' and 'Yogmaya' in Rajasthan and 'Saranya' in Bihar $[9,10]$. In tribal region of Jharkhand and Orissa sacred groves are popularly known as Jaher [11]. Though there are studies on sacred groves in India [e.g. 1,7,12-16], the Pachmarhi Biosphere Reserve of Central India in Madhya Pradesh state has not yet been explored on this aspect. Besides, the present study attempts to analyze the tribal people views on sacred groves, their traditional significance and gender issues associated with sacred groves in the Pachmarhi Biosphere Reserve.

\section{Methodology}

\subsection{Study Area}

The Pachmarhi Biosphere Reserve (PBR), one of the 15 biosphere reserves of India, lies between $20^{\circ} 10^{\prime}$ to $22^{\circ} 50^{\prime}$
$\mathrm{N}$ latitude and $77^{\circ} 45^{\prime}$ to $78^{\circ} 56^{\prime} \mathrm{E}$ longitude. PBR was established on March 3, 1999 in the Satpura Range of Madhya Pradesh. It spans over 3 districts of Madhya Pradesh - Hoshangabad, Betul, and Chhindwara. The total geographical area of PBR is $4926.28 \mathrm{sq} \mathrm{km}$, of which $524.37 \mathrm{sq} \mathrm{km}$ is under the core zone and remaining $4462.93 \mathrm{sq} \mathrm{km}$ comprises the buffer zone [17]. PBR consists of three wildlife conservation units, the Satpura National Park (524.37 sq km), the Bori Wildlife Sanctuary (518.00 sq km), and the Pachmarhi Sanctuary (461.37 sq $\mathrm{km})$. Satpuda National Park is designated as the core zone of PBR and the remaining area including the Bori and Pachmarhi sanctuaries constitutes the buffer zone (Figure 1). In general, the temperature of $\mathrm{PBR}$ ranges from $11^{\circ} \mathrm{C}$ to $42^{\circ} \mathrm{C}$ [18].

PBR endows with rich plant and animal diversity. The forest vegetation of PBR is classified as subtropical hill forest and tropical moist deciduous forest [18]. The forests in PBR provide shelter for many wildlife species

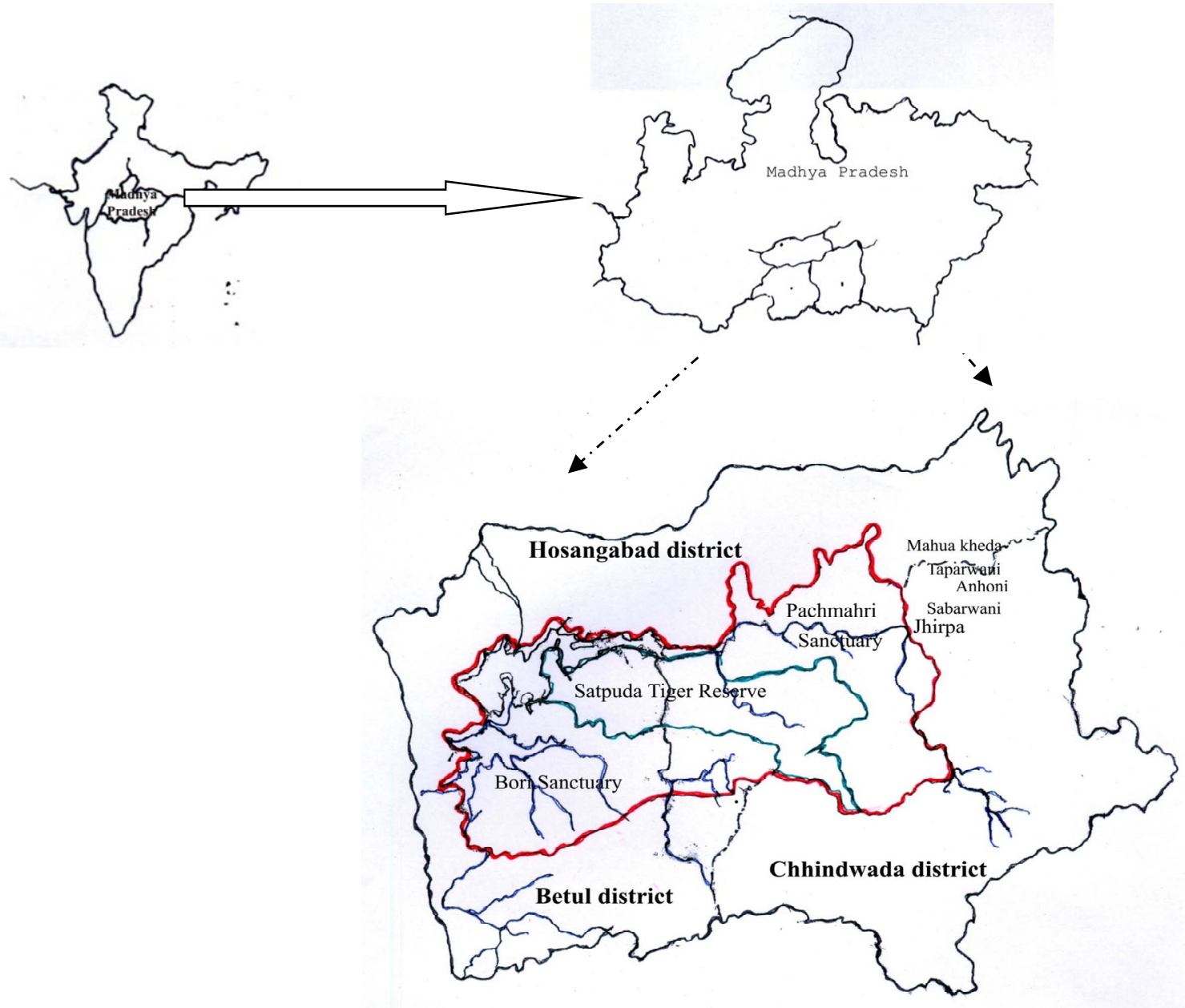

Figure 1. Location map of the Pachmarhi Biosphere Reserve in India. 
including tiger, leopard, wild boar, barking deer, guars, cheetal, and Rhesus macaque. PBR is equally known for its cultural diversity, as it is inhabited by number of tribal and non-tribal communities. The major tribal group was Gond in the study area. Because of the numerical strength, the Gond tribe dominates the central parts of India and the Central Province was known as Gondwana state, as the Gond ruled this part of India in the past [19]. The social organization of the Gond reveals that they are divided into clans, such as, Arpanche, Bariba, Dhurwe, Erpachi, Imne, Kakoria, Karskoley, Naure, Padram, Sarbeyan, Sarada, Sivarsaran, Vallabey, Barkare, Barkey, Batti, Eke, Kumre, Porta, Tekam and Wike.

\subsection{Survey Methods}

For the study of sacred groves, the villages in buffer zone areas of PBR, close to the boundary of Satpuda Tiger Reserve, were surveyed. A total of 10 villages in buffer zone of PBR namely Sawarwani, Shahwan, Fatepur, Singhpur, Anhoni, Bandi, Deokoh Bodalkachhar, Khara and Taperwani were selected for intensive study of sacred groves and associated traditional biodiversity conservation knowledge. The selected villages were dominated by tribal communities, mostly Gond and Mawasi with their offshoots (Table 1). The door to door questionnaire survey was conducted in the selected villages of PBR. In most of the villages, generally the male members were available for interviews, however, female were also cooperated during the interview.

Through questionnaire survey the information was collected on the name of sacred grove, its locality, size of grove, occurrence of plants in the sacred grove site, deities worshipped, history or folklores and gender issues associated with such groves. Besides, the local people were encouraged to give their views and perceptions on the sacred grove with respect to the cultural, ecological, economical and conservation perspectives. During the field work, the sacred grove sites were also visited with the local knowledgeable people for preparing the list of species and associated knowledge with such sacred groves. Participant observations were also employed and information was collected by participating in various cultural activities of the local tribal people.

\section{Results}

\subsection{Sacred Grove-Traditions and Values}

The study reveals the occurrence of 7 and 16 sacred groves in the study villages of the PBR managed by the Mawasi and Gond tribe, respectively (Table 2). The name of grove was given on the name of deity worshipped in the groves. A total of 19 such deities were recorded during the survey worshipped by the local people. The deities worshipped in the sacred groves may also differ across the different tribal groups and their sacred groves. There were some common deities of both Gond and Mawasi tribes, such as, Khedapati, Hardula and Budha Deo. Most of the groves were located outside the villages however some were very close to the village boundary. The average age of grove was between 150 to 200 years, as reported by the local people. The maximum size of sacred grove in the study villages was about 0.60 hectare.

The Gond and Mawasi were so keen in the sacred grove concept that still today they used to establish and earmark some areas close to newly established human settlement in case of their rehabilitation from the core zone to the buffer zone areas of the PBR. The Khedapati grove of Khamda village in PBR was one such example in which the grove was reported to establish about 35 years ago with the establishment of the village due to construction of Tawa Reservoir and subsequent rehabilitation of villagers in the buffer zone of the PBR. The villagers retained the village name - Khamda at the new site including the culture and traditions associated with biodiversity, ecosystem and environment. In view of this they selected a site and some plant species as the abode

Table 1. Profile of the major study villages.

\begin{tabular}{cccc}
\hline Villages & Total Household & Total Population & Communities \\
\hline Sawarwani & 82 & 683 & Gond, Yadav and Schedule Caste \\
Shahwan & 56 & 263 & Gond, Ray and Vishwakarma \\
Fatehpur & 27 & 290 & Gond \\
Singhpur & 210 & 1200 & Gond, Mawasi, Yadav and Ray \\
Anhoni & 120 & 775 & Gond and Yadav \\
Bandi & 35 & 500 & Gond and Karar Patel \\
Deokoh & 30 & 352 & Gond \\
Bodalkachhar & 40 & 289 & Gond \\
Khara & 105 & 820 & Gond \\
Taperwani & 48 & 362 & Gond
\end{tabular}


Table 2. Status of sacred groves in the studied villages of the PBR.

\begin{tabular}{|c|c|c|c|c|c|}
\hline Communities & Name of the Groves & $\begin{array}{l}\text { Deities Wor- } \\
\text { shipped }\end{array}$ & Plants Symbolized as Abode of Deities & $\begin{array}{l}\text { Age of the } \\
\text { Grove (Ap- } \\
\text { proximate) }\end{array}$ & $\begin{array}{l}\text { Grove size } \\
\text { (Approxi- } \\
\text { mate) }\end{array}$ \\
\hline \multirow[t]{7}{*}{ Mawasi } & Khedapati & Khedapati & $\begin{array}{l}\text { Madhuca indica, Zizyphus jujuba, Sho- } \\
\text { rea robusta Dendrocalamus strictus, } \\
\text { Ficus religiosa }\end{array}$ & 200 & 0.60 hectare \\
\hline & Sidhmaraj & Hardula baba & $\begin{array}{l}\text { Tamarindus indica, Shorea robusta, } \\
\text { Ficus benghalensis, Madhuca indica }\end{array}$ & 150 & Few trees \\
\hline & Doval Deo & Budhadeo & $\begin{array}{l}\text { Shorea robusta, Madhuca indica, Hard- } \\
\text { wickia binata Dendrocalamus strictus, } \\
\text { Ficus religeosa, Solanum nigrum, } \\
\text { Tamarindus indica }\end{array}$ & 150 & 0.40 hectare \\
\hline & Dongardeo & Dongarbuda & $\begin{array}{l}\text { Shorea robusta, Madhuca indica, Ter- } \\
\text { minalia bellirica }\end{array}$ & 200 & 0.20 hectare \\
\hline & Maile Devi & Meile & Madhuca indica & $150-200$ & \\
\hline & Hardula/ Kunwar Deo & Hardula & Madhuca indica & 200 & Few trees \\
\hline & Bari Mata & Bariyam Devi & Madhuca indica, Shorea robusta & $150-200$ & Few trees \\
\hline \multirow[t]{16}{*}{ Gond } & Khedapati & Khedapati & $\begin{array}{l}\text { Shorea robusta, Madhuca indica, Ficus } \\
\text { religiosa, Dendrocalamus strictus, Ter- } \\
\text { minalia bellirica, Ficus benghalensis, } \\
\text { Mucuna pruriens Phyllanthus sylves- } \\
\text { tris, Phyllanthus officinalis, Buchanania } \\
\text { lanzan }\end{array}$ & $200-250$ & 0.20 hectare \\
\hline & Bagh Deo & Bagh Deo & Madhuca indica & Not known & Few trees \\
\hline & Budha Deo & Budha Deo & $\begin{array}{l}\text { Shorea robusta, Dendrocalamus strictus, } \\
\text { Ficus religiosa, Butea monosperma, } \\
\text { Madhuca indica, Ficus benghalensis , } \\
\text { Aegle marmelos }\end{array}$ & Not known & 0.10 hectare \\
\hline & Sayenebuda & Sayenebuda & $\begin{array}{l}\text { Ficus benghalensis, Madhuca indica, } \\
\text { Butea monosperma, Buchanania lanzan }\end{array}$ & 150 & Few trees \\
\hline & Bari mata & Bari mata & Madhuca indica, Shorea robusta & 150 & Few trees \\
\hline & Sidhbaba & Sidhbaba & Tamarindus indica & Not known & Few trees \\
\hline & Bajranj & Bajranj & $\begin{array}{l}\text { Madhuca indica, Tamarindus indica, } \\
\text { Azadirachta indica, Anogeissus pendula, } \\
\text { Hardwickia binata }\end{array}$ & $200-300$ & Few trees \\
\hline & Hardula & Hardula & $\begin{array}{l}\text { Madhuca indica, Shorea robusta, Hard- } \\
\text { wickia binata, Butea monosperma }\end{array}$ & 150 & 0.10 hectare \\
\hline & Gowal baba & Gowal baba & Phyllanthus officinalis & $150-200$ & Few trees \\
\hline & Kuripan & Kuripan & Shorea robusta, Madhuca indica & 200 & Few trees \\
\hline & Dhobal Deo & Dhobal Deo & Madhuca indica & $150-200$ & Few trees \\
\hline & Balkhan & Balkhan & Shorea robusta & $150-200$ & \\
\hline & $\begin{array}{l}\text { Siddha Baba (water } \\
\text { god) }\end{array}$ & $\begin{array}{l}\text { Siddha Baba } \\
\text { (water god) }\end{array}$ & $\begin{array}{l}\text { Ficus benghalensis, Shorea robusta, } \\
\text { Terminalia bellirica, Hardwickia binata, } \\
\text { Butea monosperma, Calotropis gigantea, } \\
\text { Madhuca indica }\end{array}$ & Not known & 0.20 hectare \\
\hline & Nagdeo & Nagdeo & Phyllantus officinalis, Madhuca indica & Not known & 0.20 hectare \\
\hline & Gowalbaba & Gowalbaba & $\begin{array}{l}\text { Madhuca indica, Terminalia chebula, } \\
\text { Semecarpus anacardium }\end{array}$ & Not known & 0.10 hectare \\
\hline & Matabai & Matabai & $\begin{array}{l}\text { Azadirachta indica, Ficus religiosa, } \\
\text { Semecarpus anacardium }\end{array}$ & Not known & 0.10 hectare \\
\hline
\end{tabular}

of some local deities to continue their tradition. The villagers who were mainly Gond used to pay high respect to Mahuwa (Madhuca indica), as an important tree species not only for its multipurpose fruit giving nature but they used to worship the Goddess Khedapati in Madhuca in- dica in their former village.

The sacred groves were rich in plant genetic diversity. These groves were composed of many ethnobotanically useful species, including wild edible fruits, medicinal plants, fodder, fuelwood and timber yielding species. Of 
the total plant species documented from the sacred groves, the fruits of many species were used as food and also for performing various religious functions. The most important fruit yielding plants was Madhuca indica, followed by Buchanania lanzan, Ficus benghalensis and Ficus religiosa. The local people used to collect these fruits mainly for their own consumption, and sometime depending upon the quantity of collection they used to sell the produces in the local market. The Gond and Mawasi used to prepare local liquor from the flowers of Madhuca indica. People also used to collect plants for curing diseases from the sacred grove site. In some cases before collection of such medicinal plant species, they offered a coconut fruit and local liquor made of Madhuca indica.

The villagers also disclosed the fact that the soil in the sacred grove site remained more fertile than the adjacent sites of the village. This was possible due to high biomass and accumulation of high organic contents in such sites and further decomposition and nutrients release in such ecosystems. The farmers, who had agriculture land in the proximity of such sacred grove, had reported relatively higher production of grains in such lands. Besides, such farmers had noticed the higher moisture contents in their land. The local people also reported that sacred grove used to provide the shelter and food for many wildlife species including varieties of birds and butterflies.

Traditionally, some gender issues were associated with the sacred groves, especially with respect to the collection and use of resources. There were some specific periods in which the people were not allowed to enter the sacred groves. Before entering the sacred grove women were advised to take bath. During monthly menstruation women were strictly prohibited going inside the sacred groves, as there was a strong belief that it might defiled her or the deities living in the sacred grove. Similarly, the members from the deceased family were not allowed to enter the sacred grove sites until the completion of purifying rituals. The villagers generally performed the purifying ritual at $10^{\text {th }}$ days of the death of the person. People strictly followed these customary norms in view of their own welfare as well as their deities and society.

\subsection{Traditional Management of Groves}

The villagers themselves maintained the sacred groves with a great passion and sanctity. The traditional institutional mechanisms have been helping the local people in maintaining the sacred groves. The 'padihar' (saman) has given the responsibility to take care and worship the village deity in sacred groves (Figure 2). The local people were allowed to enter and worship the village deities in sacred grove. Mostly the head of the village or Padihar

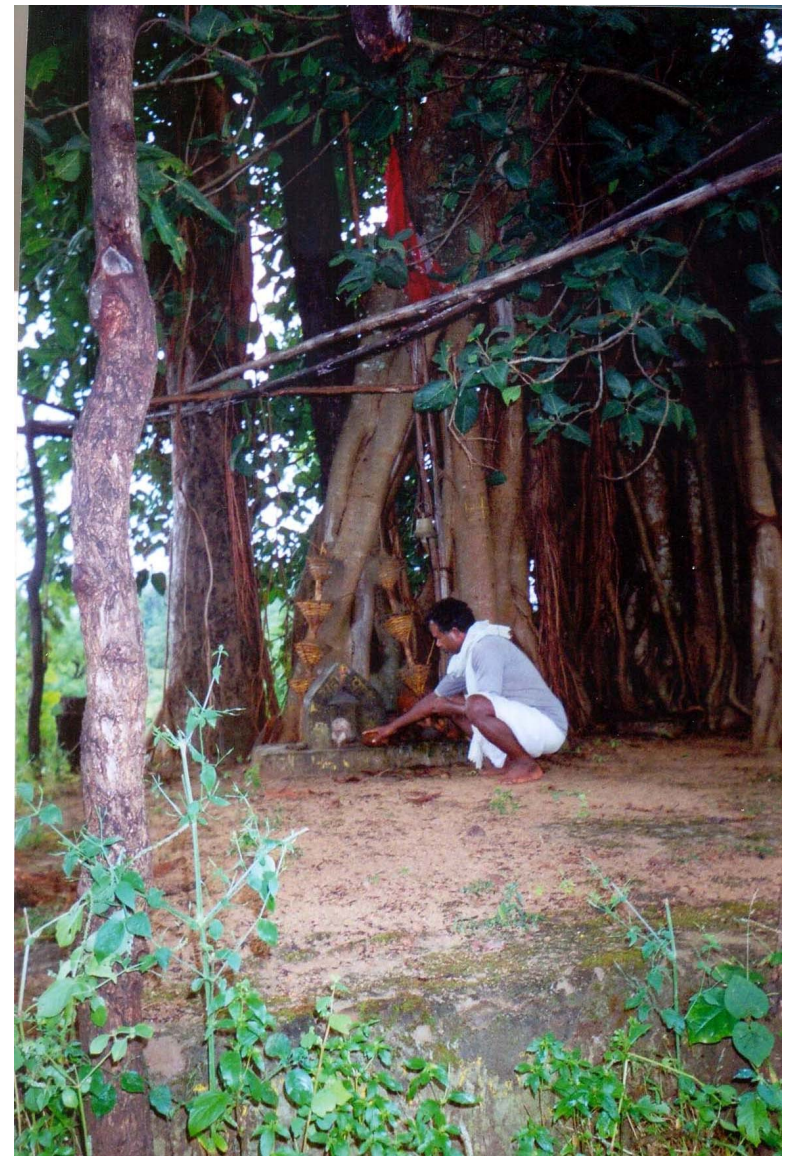

Figure 2. Worshipping deity in the sacred grove by Padiyar.

collected the fruits from the sacred grove, particularly Madhuca indica and Tamarindus indica. There were some customs and cultural practices associated with collection and generally there was no restriction on the collection of fruits, however the local people were afraid of collection from the sacred groves. There was a general belief that since sacred groves were pure, the gatherers might be punished by spirits and deities for unauthorized collection of natural resources, though all deities were not considered unsafe. People always feared to go inside the sacred grove of Khedapati, as Khedapati was acknowledged the supreme deity of the tribal communities living in PBR. A belief was also associated with the old tree species that old trees in sacred grove generally the haunt of evil spirits, and as old as the tree, greater the chances of evil spirits to inhabit. The local people feared to go to such places, even in the noon and evening. Children and pregnant women were not allowed to visit such places.

During present investigations, in 3 sacred groves, Bauhinia vahlii, an important ethnobotanical species was found. Leaf of Bauhinia vahlii was used for making cups 
and plates and the stem was used for making rope, nonetheless the individuals of this species growing in the sacred grove were not exploited for such purposes by the villagers. Besides, there was no provision of cutting the plant species from the sacred grove. In case of not following such customary norms, the lawbreaker was imposed monetary penalty by the village council.

\section{Discussion}

Gond being a dominant tribal community in the central India has enjoyed several benefits from the nature and thus has determined the uses of natural resources from historical past. Simultaneously, they have evolved strategies for the conservation of such useful and valuable biodiversity in view of their sustained availability. Gonds believe in many gods and goddess and some of the Gond deities are similar to the Hindus. Budha Deo is one of the most venerated deities of Gonds. They also worship other deities such as Bari Mata, Khedapati, Sidhbaba, Gowal baba, Bajrang, Bagh Deo, Nagdeo and Sayenebuda. The philosophy of worshipping deities in sacred groves, as practices by Gonds, is similar to many other tribal communities living in various parts of India [12,20]. Ayyappa, Aiyanar and Sasta in Southern India are the deities of woods, who used to guard the villagers and drive away their enemies [6,21]. The religious persons in Gond are Padiar (shaman) and Bhomka (priest), who enjoy a high respect in the community. Gond and Mawasi have their own calendar, which they use for different purposes including collection of forest resources, cultivation of crops and performing various religious activities.

The fear of Gods and Goddess in the community might have been used as an instrument by the Padiar and Bhomka for smooth functioning of society and maintaining social cohesiveness. The concept of sacred groves that revolves around the religious beliefs has brought some special significance in the life of Gonds and their associated tribal groups such as Mawasi in the study area. The customary rules established by these tribal groups, especially with respect to the sacred groves, have paved the way for conservation of biodiversity from the historical past.

The established customary rules may vary from place to place and grove to grove but the goal is same, which follows the similar philosophy. These traditional rules often prohibit the felling of trees and the killing of animals, except when trees are required for the construction and repair of religious buildings or in special cases do allow collection of firewood, fodder, and medicinal plants by local people $[22,23]$. As a result of these restrictions, the biodiversity in such sacred groves are preserved over many generations, and still exist today. The sacred groves are the last home of some endangered species, as observed in Kodagu district of southern Indian state of Karnataka [24], and also are known to represent the only exiting climax vegetation communities in northeastern India [23]. Numbers of studies have supported the role of sacred grove in conservation of biodiversity across the different parts of India including West Bengal [25], Northeast India [26] and Eastern Ghats [12].

In PBR, besides conservation of biodiversity, the role of sacred groves is also important as a life support system. The sacred groves help tribal communities by providing edible fruits, leaves, fibers and medicinal plants. The people viewed that the required species if not found elsewhere around their village surroundings, there are high probability of occurrence of such species in the sacred grove sites by the grace of their local deity. At present, when in most parts of the world the forest cover and the biodiversity are dwindling; these sacred groves are increasingly being recognized as the stronghold for precious biological species. More than 130 major ethnic communities live in eastern Himalayan region of India and it was not uncommon in the past to locate here one sacred grove maintained by each village community [20].

The motive behind the foundation and evolution of such sacred groves may vary. However, it has been shattered in many parts of the world, especially in Europe, Central Asia and Middle East, where sacred groves have perished often without leaving a trace [6]. In contemporary period there is a great concern of the people as well as scientists working in the biodiversity conservation on the management of such sacred groves. In few places within India the sacred sites and sacred landscapes are also reported threatened by various external factors [1,2]. It has led to the declining of plant species and other materials from the sites. It is perceived that the sacred groves are not only important for religious values, which contribute significantly in maintaining the village ecosystem and surrounding biodiversity [7], but they are also culturally rich and living place of deities and spirits, which has larger significance.

Given the importance of sacred groves in the conservation of biodiversity and ecosystem, there is a need to take care of such sites, and attempts should be made to maintain the sanctity of these sacred groves. People must be made aware of such traditional conservation practices and they should bear its sanctity and values in mind while looking into commercial interests. It is important to develop management approaches in order to encourage the conservation of sacred groves. It is a need of hour to recognize the values of traditional institutions of sacred groves, the existing evidence for their effectiveness in biodiversity conservation and create space for such con- 
cepts while framing local, regional and national conservation policies and planning.

\section{Acknowledgements}

I thank the Director, Indian Institute of Forest Management, for providing logistic support. Bhubaneswar Saber is acknowledged for helping in collection of field data. The project was funded under the grant IIFM/RP-Int./CPK/2009$11 / 04$.

\section{REFERENCES}

[1] P. S. Ramakrishnan, "What is Traditional Ecological Knowledge?” In: P. S. Ramakrishnan, R. K. Rai, R. P. S. Katwal and S. Mehndiratta, Eds., Traditional Ecological Knowledge for Managing the Biosphere Reserve in South and Central Asia, Oxford University Press, New Delhi, 2002, pp. 3-12.

[2] C. P. Kala, "Ethnobotanical and Ecological Approaches for Conservation of Medicinal and Aromatic Plants," Acta Horticulturae, Vol. 860, 2010, pp. 19-26.

[3] B. S. Sajwan and C. P. Kala, "Conservation of Medicinal Plants: Conventional and Contemporary Strategies, Regulations and Executions”, Indian Forester, Vol. 133, No. 4, 2007, pp. 484-495.

[4] S. Tokarev, "History of Religion,” Progress Publishers, Moscow, 1989.

[5] J. D. Hughes, "Pan's Travel: Environmental Problems of the Ancient Greek and Romans,” Johns Hopkins University Press, Baltimore, 1990.

[6] B. Gowda, "Sacred Plants," Kalpataru Research Academy, Bangalore, 2006.

[7] M. Gadgil, F. Berkes and C. Folke, "Indigenous Knowledge for Biodiversity Conservation,” A Journal of the Human Environment, Vol. 22, 1993, pp. 151-156.

[8] K. C. Malhotra, Y. Ghokhale, S. Chatterjee and S. Srivastava, "Cultural and Ecological Dimensions of Sacred Groves in India,” INSA, New Delhi, 2001.

[9] B. Ramachandran, "Significance of Kavu-A Note on the Sacred Grove of Kerala in Eco-Cultural Context," Journal of Human Ecology, Vol. 10, No. 4, 1999, pp. 285-288.

[10] P. Joshi and Y. Shrivastava, "Drops of Nature Conservation-Sacred Grove,” Journal of Human Ecology, Vol. 11, No. 5, 2000, pp. 327-330.

[11] V. Хaxa, "Oraons: Religion, Custom and Environment," In: G. Sen, Ed., Indigenous Vision, Saga Publication, New Delhi, 1991, pp. 101-109.

[12] M. Gadgil and V. D. Vartak, "Sacred Groves of Western Ghats in India," Economic Botany, Vol. 30, 1976, pp. 152-160. doi:10.1007/BF02862961
[13] V. D. Vartak and M. Gadgil, "Studies on Sacred Groves along the Western Ghats from Maharashtra and Goa: Role of Beliefs and Folklores,” In: S. K. Jain, Ed., Glimpses of Indian Ethnobotany, Oxford University Press, Bombay, India, 1981, pp. 272-278.

[14] M. Gadgil and F. Berkes, "Traditional Resource Management Systems,” Resource Management and Optimization, Vol. 18, 1991, pp. 127-141.

[15] V. Bhasin, "Religious and Cultural Perspective of a Sacred Site - Sitabari in Rajasthan,” Journal of Human Ecology, Vol. 10, 1999, pp. 329-340.

[16] S. A. Bhagwat and C. Rutte, "Sacred Groves: Potential for Biodiversity Management," Frontiers in Ecology and the Environment, Vol. 4, No. 10, 2006, pp. 519-524. doi:10.1890/1540-9295(2006)4[519:SGPFBM]2.0.CO;2

[17] EPCO, "Pachmarhi Biosphere Reserve,” Environmental Planning and Co-ordination Organization, Bhopal, 2001.

[18] E. A. Jayson, “An Ecological Survey at Satpura National Park, Pachmarhi and Bori Sanctuaries, Madhya Pradesh,” Indian Journal of Forestry, Vol. 13, No. 4, 1990, pp. 288-294.

[19] C. P. Kala, "Home Gardens and Management of Key Species in the Pachmarhi Biosphere Reserve of India,” Journal of Biodiversity, Vol. 1, No. 2, 2010, pp. 111-117.

[20] C. P. Kala, "Ethnomedicinal Botany of the Apatani in the Eastern Himalayan Region of India,” Journal of Ethnobiology and Ethnomedicine, Vol. 1, 2005, pp. 1-12. http://www.ethnobiomed.com/content/pdf/1746-4269-1-11. pdf

[21] P. C. Alexander, "Buddhism in Kerala," Annamalai University Historical Series, No. 8, Madras, 1949.

[22] D. Brandis, "Indigenous Indian Forestry: Sacred Groves," Oriental Institute, England, 1897.

[23] P. S. Ramakrishnan, "Conserving the Sacred for Biodiversity: The Conceptual Framework,” In: P. S. Ramakrishnan, K. G. Saxena and U. M. Chandrashekara, Eds, Conserving the Sacred for Biodiversity Management, Oxford and IBH Publishing Co., New Delhi, 1998, pp. 3-16.

[24] S. A. Bhagwat, C. G. Kushalappa, P. H. Williams and N. D. Brown, “A Landscape Approach to Biodiversity Conservation of Sacred Groves in the Western Ghats of India,” Conservation Biology, Vol. 19, No. 6, 2005, pp. 1853-1862. doi:10.1111/j.1523-1739.2005.00248.x

[25] P. K. Pandit and R. K. Bhakat, "Conserving of Biodiversity and Ethnic Culture through Sacred Groves in Midnapore District, West Bengal, India,” Indian Forester, Vol. 133, No. 3, 2007, pp. 323-344.

[26] A. D. Khumbongmayum, M. L. Khan and R. S. Tripathi, "Sacred Groves of Manipur-Ideal Centres of Biodiversity Conservation,” Current Science, Vol. 87, 2004, pp. 430-433. 